\title{
กระบวนวิธีการตรวจสอบและประเมินกำลังรับน้ำหนักของสะพานอนุรักษ์ ในกรุงเทพมหานครย
}

สัจจรักษ์ พรพีรเกียรติ ${ }^{*}$ กฤษชัย ศรีบุญมา ${ }^{1}$ สันชัย อินทพิชัย ${ }^{2}$ พานิช วุฒิพฤกษ์ และ อัญมนี ภูชิน ${ }^{3}$

\section{บทคัดย่อ}

สะพานอนุรักษ์พิจารณาจากอายุการใช้งานมากกว่า 75 ปี โดยในพื้นกรุงเทพย มีสะพานเหล่านี้มากกว่า 10 แห่งซึ่ง ถือเป็นความสำคัญในการอนุรักษ์เชิงสถาปัตยกรรมอีกทั้งยังคงเปิดใช้งานในปัจจุบัน ทั้งนี้มาตรฐานการออกแบบ สะพานเก่าเหล่านี้ไม่เพียงพอต่อการอ้างอิงด้านความแข็งแรงของโครงสร้างจึงจำเป็นต้องได้รับการตรวจสอบด้านกำลัง ทั้งเชิงการทดสอบ และการวิเคราะห์เพื่อปรับปรุงกำลังรับน้ำหนักบรรทุกให้สามารถใช้งานได้อย่างปลอดภัยในภาวะ ปัจจุบัน งานวิจัยนี้นำเสนอกระบวนการตรวจสอบสภาพและประเมินกำลังการรับน้ำหนักของสะพานอนุรักษ์อ้างอิงตาม มาตรฐานปัจจุบัน โดยระเบียบวิธีการที่นำเสนอได้ลำดับแยกย่อยในกระบวนการวิธีการตรวจสอบซึ่งครอบคลุมการ ตรวจสอบโครงสร้างสะพานอนุรักษ์ ในทั้งการทดสอบวัสดุเชิงกายภาพ การทดสอบเชิงสถิตย์และพลศาสตร์ การสร้าง แบบจำลองเชิงคณิตศาสตร์ และการประเมินสภาวะการรับน้ำหนักของสะพาน ผลที่ได้สามรถนำไปเป็นแนวทางปฏิบัติ เพื่อประเมินโครงสร้างสะพานเก่าภายใต้สภาวะการใช้งานปัจจุบัน ทั้งนี้กระทำการตรวจสอบสามารถทำได้ในเชิง กายภาพและเชิงตัวเลขไปพร้อมกัน การประเมินที่ได้สามารถระบุถึงความสามารถในการรับกำลัง ซึ่งหากไม่เข้าเกณฑ์ที่ กำหนดสะพานอนุรักษ์นั้น ๆ จะถูกเสริมกำลังเพื่อให้สามารถรับน้ำหนักใช้งานปัจจุบันได้อย่างปลอดภัย

คำสำคัญ: การตรวจสอบสะพานอนุรักษ์ การวิเคราะห์โครงสร้างแบบไม่เป็นเชิงเส้น ธรณีเทคนิควิเคราะห์ของ สะพาน สภาวะการรับน้ำหนักของสะพาน

\footnotetext{
${ }^{1}$ อาจารย์ ดร., ภาควิชาครุศาสตร์โยธา คณะครุศาสตร์อุตสาหกรรม มหาวิทยาลัยเทคโนโลยีพระจอมเกล้าพระนครเหนือ ${ }^{2}$ รองศาสตราจารย์ ดร., ภาควิชาครุศาสตร์โยธา คณะครุศาสตร์อุตสาหกรรม มหาวิทยาลัยเทคโนโลยีพระจอมเกล้าพระนครเหนือ 3 เลขานุการโครงการ, ภาควิชาครุศาสตร์โยธา คณะครุศาสตร์อุตสาหกรรม มหาวิทยาลัยเทคโนโลยีพระจอมเกล้าพระนครเหนือ * ผู้นิพนธ์ประสานงาน โทร: 0-2587-8260 อีเมล: sacharuck.p@fte.kmutnb.ac.th
} 


\title{
Inspection and Strength Evaluation of the Historical Bridges in Bangkok
}

\author{
Sacharuck Pornpeerakeat ${ }^{1 *}$ Krissachai Sriboonma $^{1}$ Sunchai Inthapichai ${ }^{2}$ Panich Voottipruex ${ }^{2}$ \\ and Anyamanee Phoochin ${ }^{3}$
}

\begin{abstract}
In the Bangkok zone, historical bridges, defined as bridges built more than 75-year old, are observed more than 10 bridges. These bridges are valuable in both architecture and existing-traveling purposes. With the old design practice, the strength of the historical bridge might not be safe and sufficient for carrying the current traffic loads. Therefore, an inspection and strength evaluation of the historical bridges shall be standardized. This paper provides procedures for structural adequacy assessment of historical bridges in Bangkok zone, which consists of a combination of physical inspections, static and dynamic load tests, a nonlinear analysis, and a method for condition load rating. A guideline of techniques for inspection of long serviced bridges under the present service condition is also provided. In addition, physical inspection and numerical analysis are carried out in parallel to obtain a specification for strengthening the historical bridges in order to gain an operational load rating.
\end{abstract}

Keywords: Bridge Inspections, Nonlinear Analysis of Structures, Geotechnical Analysis of Bridges, Bridge Load Rating

\footnotetext{
${ }^{1}$ Dr., Department of Technical Training in Civil Engineering, Faculty of Technical Education, King Mongkut's University of Technology, North Bangkok

${ }^{2}$ Associate Professor Dr., Department of Technical Training in Civil Engineering, Faculty of Technical Education, King Mongkut's University of Technology, North Bangkok

${ }^{3}$ Project Secretary, Department of Technical Training in Civil Engineering, Faculty of Technical Education, King Mongkut's University of Technology, North Bangkok

* Corresponding Author Tel: 0-2587-8260 Email: sacharuckp@kmutnb.ac.th
} 


\section{Introduction}

Bridges are very important for the city's infrastructure since the ancient time, making transportations possible across the river for trading, commence and military purposes. For some special occasions, bridges were built for royal celebrations or memorials. These bridges related to the historical events, marking the civilization of the country.

In the history of Siam which in the present day is Thailand. At the time of founding the capital of Siam, well-known to foreigners as "Bangkok", most of the Siamese population lived by canals and the Chaopraya River. The canals are connected as the network throughout inner Bangkok. Because of the waterways and the canal networks, Bangkok was also known as "Venice of the east".

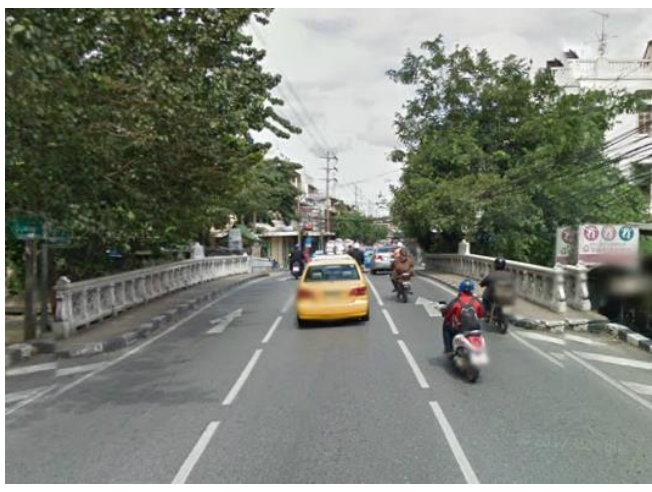

Fig. $1 \mathrm{~A}$ historical bridge in the present service load

During the King Rama V's reign (H.M. the King Chulalongkorn of Siam), buildings such as government offices and bridges were greatly influenced by western architectures. Many historical or memorial bridges built in the western style are still being used as road bridges for Bangkok's traffic today.

Up to the present, the historical bridges from the King Rama V's era are still in service for the traffic transportation and become the city's landmarks around the Bangkok. In term of historical bridges herein, therefore, focus on the bridge built more than 75-year old.

Since these old bridges have been in service for road traffic for a very long time, the requirement for rehabilitation is concerned. The objectives of the rehabilitation include: (1) to maintain the bridges capacity for current traffic loading, (2) to ensure that the city's historical and architectural landmarks still remarkable for tourists, and (3) to stage royal ceremonies.

Figure 2 summarizes three key factors for evaluating the historical bridges including Architectural, Material Testing, and Structural and Geotechnical Analysis. These can be done by physical inspection, load test simulations (truck loading), and numerical analysis of Super- and Substructure.

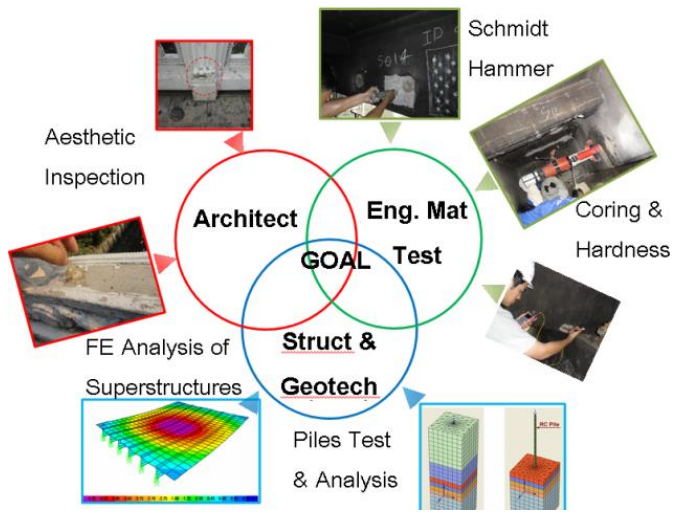

Fig. 2 Evaluation procedure outline

\section{Material Testing}

Existing properties of historical bridges are required for strength evaluation. This can be done by six standard procedures listed in Table 1. 
Table 1 Lists of material testing methods

\begin{tabular}{|c|c|}
\hline $\begin{array}{l}\text { Ferro Scan Method } \\
\text { (ASTM A615) [1] }\end{array}$ & $\begin{array}{l}\text { Ferro scan is used for examining the } \\
\text { location of reinforcing steel bars and their } \\
\text { sizes. This data is used for the reinforced } \\
\text { concrete section capacity evaluation and } \\
\text { determining reinforcing steel bar layout in } \\
\text { the member. }\end{array}$ \\
\hline $\begin{array}{l}\text { Schmidt Hammer Test } \\
\text { (ASTM C805) [2] }\end{array}$ & $\begin{array}{l}\text { Schmidt hammer test is a non-destructive } \\
\text { test used for inspecting the concrete } \\
\text { compressive strength. }\end{array}$ \\
\hline $\begin{array}{l}\text { Core sampling Test } \\
\text { (ASTM C42) [3] }\end{array}$ & $\begin{array}{l}\text { Core sampling is used for evaluating the } \\
\text { existing concrete compressive strength. } \\
\text { This process will be required if the } \\
\text { strength observed by Schmidt hammer } \\
\text { varies in many cases }\end{array}$ \\
\hline $\begin{array}{l}\text { Hardness Test } \\
\text { (ASTM A956-12) [4] }\end{array}$ & $\begin{array}{l}\text { Hardness test is used for evaluating the } \\
\text { existing yield strength of the reinforcing } \\
\text { steel bars. }\end{array}$ \\
\hline $\begin{array}{l}\text { Carbonation and } \\
\text { Chloride Test } \\
\text { (ASTM C876-09), } \\
\text { (ASTM C1152) }[5,6]\end{array}$ & $\begin{array}{l}\text { Carbonation and Chloride test is for } \\
\text { evaluating the existing carbonation of the } \\
\text { concrete structure and concrete members' } \\
\text { degradation due to chemical reactions. }\end{array}$ \\
\hline $\begin{array}{l}\text { Half Cell Potential Test } \\
\text { ASTM C876-91(1999) } \\
\text { [7] }\end{array}$ & $\begin{array}{l}\text { Half Cell Potential is used for examining } \\
\text { degradation due to corrosion of the } \\
\text { reinforcing steel bars inside concrete } \\
\text { members }\end{array}$ \\
\hline
\end{tabular}




\section{Static and Dynamics Load Test}

The material testing listed in the previous section is used for materials characterization and finding the materials' properties in order to create the numerical simulation. The physical measurements data are used as data for the boundary conditions of the bridges' numerical model and also as for validation of the model. The measurement devices are shown in Fig. 3 , which consist of data logger and data acquisition system.

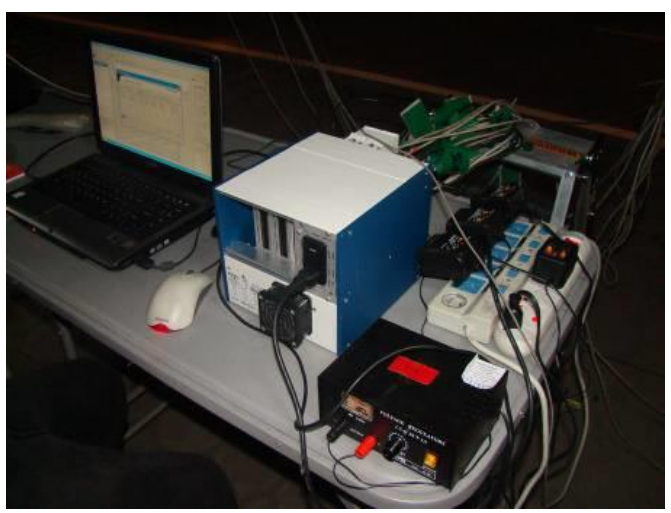

Fig. 3 Sets of data logger and data acquisition system

Figure 4 shows a schematic for equipment set up to determine dynamic response to the superstructure including strain gage, displacement transducer, accelerometer and tilt meter. The sampling rate of the measuring devices is above 100-data points per second and the measurements are made at more than 20 locations on each bridge.

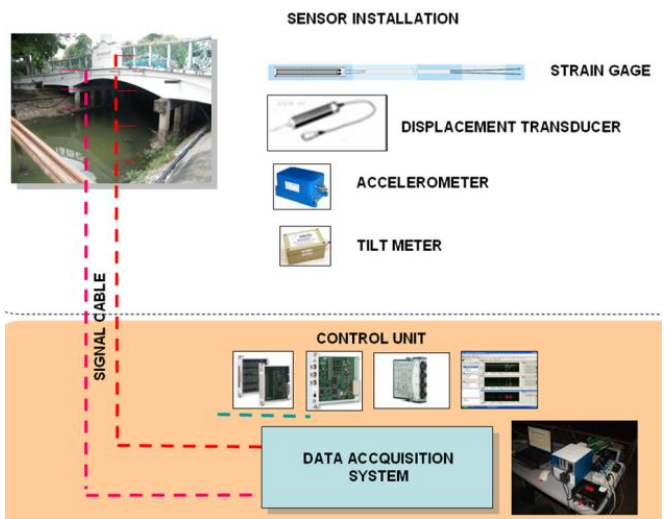

Fig. 4 Schematic for typical bridge load test of superstructure: strain gage, displacement transducer, accelerometer and tilt meter

Prior to the strengthening process, the load carrying capacity of the historical bridges are evaluated both in static and dynamic load tests The equivalent static load test is carried out by moving truck loads across the bridge at certain points of $1 / 4$, $1 / 2$ and $3 / 4$ of the span length. The dynamic load test, in the other hand, carried out by a single truck load ran across the bridge with speed rating of 5,20 and $40 \mathrm{~km} / \mathrm{hr}$.

The schematic describing the truck load test both static and dynamic process is shown in Fig.5. The load pattern depends on number of lane and a width of the bridge.
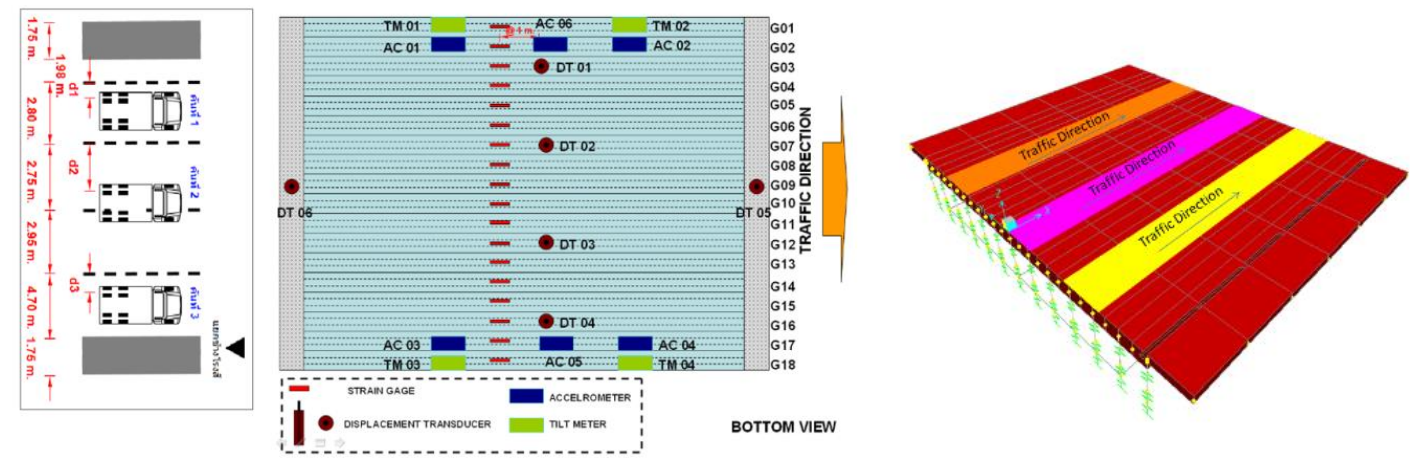

Fig. 5 the schematic diagram of truck load pattern, the equipment test set up, and lane load in FEA model 
The data collected from field tests (bridge section and physical inspection) and material testing is implemented as input information for finite element modelling. The results obtained from the finite element simulations are then employed for the determination of the required strengthening process. Figure 6 shows a diagram describing the aforementioned flowing of data.

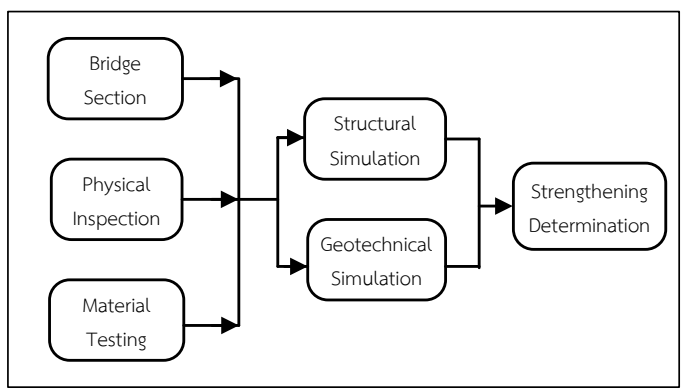

Fig. 6 A flow diagram of information required for strengthening determination

One of important data obtained from the dynamic load test is the dynamic amplification factor or known as "DAF" [9]. This parameter is comparable to static parameter in the term of an impact factor. The parameter plays a crucial role in the inventory and operating rating factor $[10,11]$ which can be obtained by using Peak Picking Method, Fast Fourier Transform Analysis, Power Spectral Density Analysis, Cross-Spectral Density Analysis and ARMA Time Series Method (PP, FFT, PSD, CSD and AR) [9] respectively.

For the static load test, the key measurements are the strain and displacement under the equivalent static loading. The key measurements for the dynamic load test, however, require additional parameters: structural responses (acceleration, natural frequency, damping and dynamic response) under the dynamic moving load and the dynamic properties (dynamic amplification factor). Figure 7 displays the method for evaluating the static and dynamic responses and the required parameters.

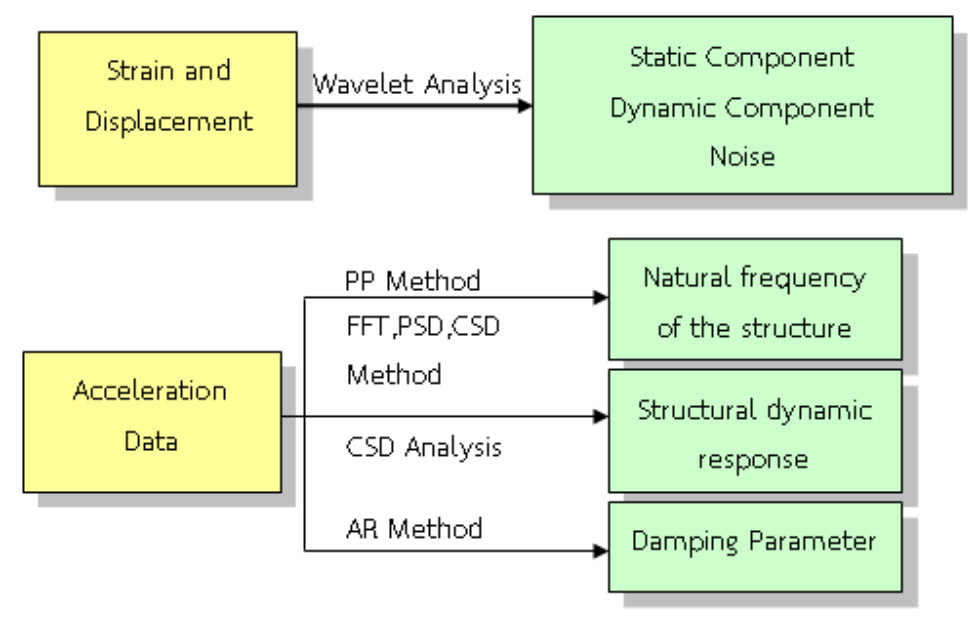

Fig. 7 The method for evaluating the static and dynamic response and parameters

\section{Structural Engineering Simulation and}

\section{Evaluation}

After obtaining the preliminary data from the previous session, physical and material testing data are evaluated for assessment of the bridge's current condition. In this part, these parameters are input into the numerical model and finally provided the results in term of the load rating factor referring to the AASHTO HS20-44 method [10, 11]. A three-dimension 
structural finite element model [8] is employed for the numerical simulation.

The structural engineering simulation is summarized in Fig 8 . The response of the structure according to the internal resisting forces such as moment and shear forces can be obtained from the simulation. The bridge condition is to be determined in terms of the inventory and operating rating factor. The inventory rating factor is related to load, including loads in multiple lanes that can safely utilize the bridge for an indefinite period of time. On the other hand, the operating rating factor is related to the maximum permissible live load that can be placed on the bridge.

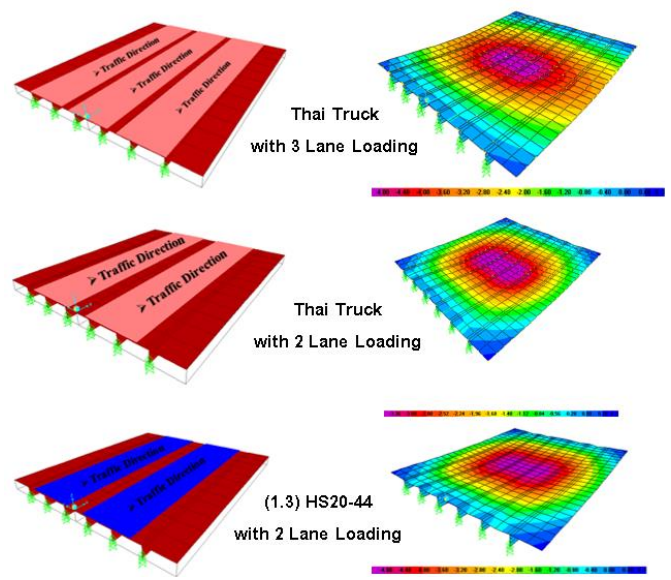

Fig. 8 Structural engineering simulation using Finite Element Method

The equation of inventory and operating rating presents in Eqn. (1) and Eqn. (2) respectively as written in the following:

$$
\begin{aligned}
& R F_{\text {inv }}=\frac{R_{U C}-1.3 R_{D L}}{2.17 R_{L L}(1+I)} \\
& R F_{\text {opr }}=\frac{R_{U C}-1.3 R_{D L}}{1.3 R_{L L}(1+I)}
\end{aligned}
$$

Where:

$$
\begin{aligned}
& R F_{\text {inv }}=\text { Inventory Rating Factor } \\
& R F_{\text {opr }}=\text { Operation Rating Factor }
\end{aligned}
$$

$$
\begin{aligned}
R_{U C} & =\text { Ultimate capacity of the member } \\
R_{D L} & =\text { Dead load effect on the member } \\
R_{L L} & =\text { Live load effect on the member } \\
I & =\text { Impact Factor }
\end{aligned}
$$

In the case of the parameter of Dynamic Amplification Factor (DAF) which is obtained from the previous session, it depends on the impcact factor (I) in Eqn. (3) as follows

$$
I=D A F-1
$$

The inventory and operating rating factor are determined for structural strengthening evaluation purposes.

\section{Geotechnical Engineering Simulation and Evaluation}

Another important factor of the bridge capacity evaluation is the geotechnical engineering criterion. For the geotechnical simulation, the procedure is similar to that of structural ones. Instead of data collecting from superstructure, the simulations require data obtaining from substructure. To simulate the behavior of the bridge pier, the displacement data at the pier or abutment due to Thai Truck 25 tons ( $\mathrm{TH} 25)$ is required. This can be done by monitoring data from displacement transducer and strain gage placed at the pier as shown in Fig. 9.

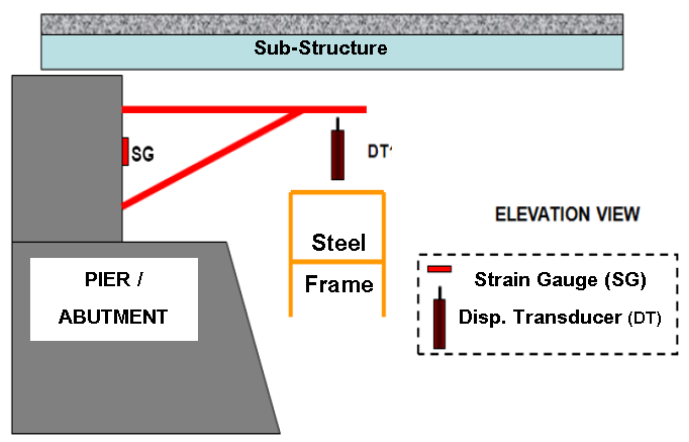

Fig. 9 Typical set-up of the strain gauge and the displacement transducer and at the pier 
Additional information to be input into the numerical model is the size of the reinforced concrete piles of the pier. The size of the pile can be obtained using the parallel seismic test data of each pile which their dimensions can then be determined. The internal resistance parameters obtained using the parameters listed in Table 2 can use for simulating the bridge pier response and is to be compared with the actual measured capacity. This simulation evaluates the limit loading of the pier capacity. The Elasto-Plastic response of Mohr-Coulomb's failure criterion [12, 13] is employed in the finite element simulation with the nonlinear analysis. These procedures are summarized in Fig.11 and Fig. 12

Table 2 The preliminary determination data for soil layers and their parameters of the elasto-plastic Mohr-

Coulomb's failure criterion $[12,13]$ of the soil element

\begin{tabular}{|c|c|c|c|c|c|}
\hline Depth & Soil layer & $\begin{array}{l}\text { Unit weight } \\
\left(\mathrm{kN} / \mathrm{m}^{3}\right)\end{array}$ & $\begin{array}{l}\text { Cohesion } \\
(\mathrm{kPa})\end{array}$ & $\begin{array}{l}\text { Friction angle } \\
\text { (degree) }\end{array}$ & $\begin{array}{l}\text { Modulus of } \\
\text { elasticity } \\
(\mathrm{kPa})\end{array}$ \\
\hline $0-13.5$ & $\begin{array}{l}\text { Soft to } \\
\text { medium stiff } \\
\text { clay }\end{array}$ & 17 & 25 & 0 & 5000 \\
\hline $13.5-19.0$ & $\begin{array}{l}\text { Stiff to very } \\
\text { stiff clay }\end{array}$ & 19 & 80 & 0 & 16000 \\
\hline $19.0-20.5$ & Stiff clay & 20 & 60 & 0 & 12000 \\
\hline $20.5-22.0$ & Very stiff clay & 20 & 100 & 0 & 200000 \\
\hline $22.0-23.5$ & Very stiff clay & 20 & 100 & 0 & 200000 \\
\hline $23.5-25.0$ & $\begin{array}{l}\text { Dense to very } \\
\text { dense sand }\end{array}$ & 20 & 1 & 35 & 100000 \\
\hline $25.0-35.0$ & Dense sand & 20 & 1 & 40 & 200000 \\
\hline
\end{tabular}
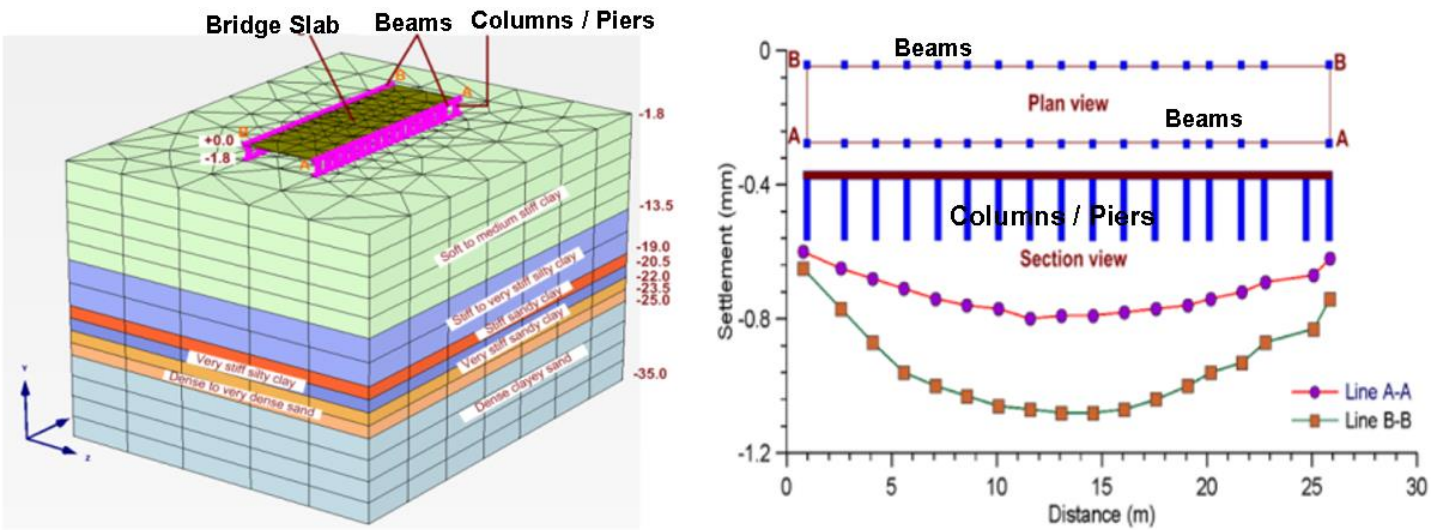

Fig. 11 Simulation of the bridge's pier and displacement response under Thai Truck 25 tons (TH25) 

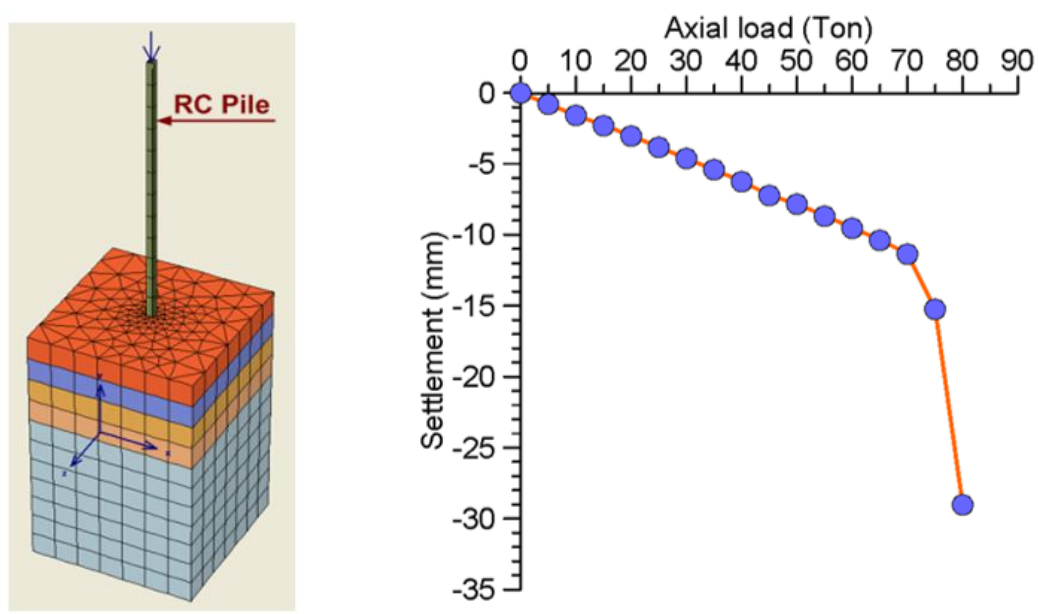

Fig. 12 Elasto-Plastic analysis of the reinforced concrete pile capacity

\section{Concluding Remarks}

This paper presents guideline procedures needed for evaluating the strength of the historical bridges under current loading resistant condition. The appropriate procedures comprise material testing, physical field tests, assessment evaluation using load rating method, and numerical simulation of both super- and sub-structure as analyzed with structural and geotechnical Finite Element Method. The data and analyses obtained from the presented procedures are also to be used as information for the consideration of an appropriate structural strengthening process [14-17] with typical steel and concrete techniques or utilizing Fiber Reinforced Polymer (FRP). The latter case has technique used for historical bridges presented in reference [18].

\section{Acknowledgement}

The project is under the report of Bangkok historical bridge evaluation and rehabilitation, which was funded by the Bangkok Metropolitan Office. The gratitude is given to the members of the King Mongkut's University of North Bangkok, Thammasart University and PYS Construction Co., Ltd.

\section{Reference}

[1] ASTM A615, "Standard Specification for Deformed and Plain Billet-Steel Bars for Concrete Reinforcement"

[2] ASTM C805, "Standard Test Method for Rebound Number of Hardened Concrete"

[3] ASTM C42, "Standard Test Method for Obtaining and Testing Drilled Cores and Sawed Beams of Concrete"

[4] ASTM A956-12, "Standard Test Method for Leeb Hardness Testing of Steel Products"

[5] ASTM C876 - 09, "Standard Test Method for Corrosion Potentials of Uncoated Reinforcing Steel in Concrete"

[6] ASTM C1152, "Standard Test Method for AcidSoluble Chloride in Mortar and Concrete"

[7] ASTM C876, "Standard Test Method for HalfCell Potentials of Uncoated Reinforcing Steel in Concrete" (Withdrawn 2008)

[8] Bathe K. J. (1996)."Finite Element Procedure", Prentice Hall.

[9] Chopra A. K. (2000). "Dynamics of Structures: Theory and Applications to Earthquake Engineering", $2^{\text {nd }}$ Edition, Prentice Hall. 
[10] AASHTO, "LRFD Bridge Design Specification SI Units", $3^{\text {rd }}$ Edition.

[11] AASHTO, 1994, "Manual for Condition Evaluation of Bridges".

[12] Rene de Borst, Crisfield M.A., Remmers J.J.C., Verhoosel C.V., "Nonlinear Finite Element Analysis of Solids and Structures", $2^{\text {nd }}$ Edition.

[13] Chen W.F., Liu X.L. (1990). "Limit Analysis in Soil Mecanics, Developments in geotechnical engineering", Elsveier.

[14] ACl-ASCE Committee 343 (ACl 343R-95), 1995, "Analysis and Design of Reinforced Concrete Bridge Structures".

[15] ACl Committee 318 (ACl318M-08), 2008, "Building Code Requirements for Structural Concrete and Commentary".

[16] ACl Committee 364 (ACl364.1R-07), 2007, "Guide for Evaluation of Concrete Structures before Rehabilitation".

[17] $\mathrm{ACl}$ Committee 440 (ACl 440.2R-08), 2008, "Guide for the Design and Construction of Externally Bonded FRP Systems for Strengthening Concrete Structures".

[18] Sriboonma, K., Pornpeerakeat, S., and Inthapichai, S. (2014). "Inspection and Load Capacity Evaluation of Bangkok Historical Bridges", NCCE $19^{\text {th }}$, Khon Kaen, Thailand. 